Nevşehir Bilim ve Teknoloji Dergisi Cilt 4(2) 75-90 2015

DOI: $10.17100 /$ nevbiltek.210941

URL: http://dx.doi.org/10.17100/nevbiltek.210941

\title{
Demir Çelik Sektörüne Genel Bir Bakış ve Beş Milyon Ton Üstü Demir Çelik İhracatı Yapan Ülkelerin Kümeleme Analizi ile İncelenmesi
}

\author{
Taner ERSÖZ ${ }^{1}$, Muharrem DÜĞENCI ${ }^{2}$, Muharrem ÜNVER ${ }^{2 *}$, Berkay EYIOL ${ }^{2}$ \\ ${ }^{1}$ Karabük Ün., İsletme Fak., Aktüerya ve Risk Yönetimi Bölümü, 78050 Karabük \\ ${ }^{2}$ Karabük Ün., Mühendislik Fak., Endüstri Mühendisliği Bölümü, 78050 Karabük
}

$\ddot{0} \mathbf{z}$

Bu çalışma, Demir -Çelik ihracat göstergesi açısından Türkiye ve Dünya ülkelerinin bir karşılaştırmasını yapmaktadır. Türkiye ve Dünya için önemli bir sektör olan Demir - Çelik sektörü küresel ekonomide de oldukça önemli bir yere sahiptir. Yüksek düzeyde demir-çelik ürünleri ihracı yapan ülkelerin karşılaştırılmasında, tüm ülkeler için dikkate değer bir seviye olan beş milyon ton ihraç seviyesi kabul edilmiştir. Bu seviyede ihraç yapan ülkeler, çok değişkenli istatistikî tekniklerden biri olan Kümeleme Analizi kullanılarak değerlendirilmiş ve karşılaştırılmıştır. Bu karşılaştırma, Türkiye'nin ülke ekonomisi ve sanayileşmesinde lokomotif sektör özelliğine sahip Demir -Çelik ihracatının hangi düzeyde olduğunun görülebilmesi açısından önemlidir.

Anahtar Kelimeler: Türkiye ve Dünyada Demir-Çelik Sektörü, Demir-çelik İhracatı, Kümeleme Analizi

\section{A General Overview Of The Iron And Steel Sector And An Examination Of Over Five Million Tons Of Iron And Steel Exporting Countries By The Cluster Analysis}

\begin{abstract}
This study makes a comparison of indicators in terms of iron and steel exports from Turkey and other countries of the world. Iron and steel sector is an important sector for Turkey and the world that has a very important place in the global economy. The comparison of the country with high levels of iron and steel products exported minimum five million tonnes exported level, a level considered value for all countries was adopted. Exporting countries that at this level, one of the multivariate statistical techniques which evaluated and compared with using Clustering Analysis. In this comparison, it is important that, Turkey's economy and industrialization in all countries with a leading sector in terms of iron and steel export feature can be seen in its cluster.
\end{abstract}

Keywords: İron and steel sector in Turkey and World, Export of iron and steel, Clustering Analysis

\footnotetext{
*e-mail :muharremunver@karabuk.edu.tr
} 
Ersöz T., Düğenci M., Ünver M., Eyiol B.

1. Giriş

Demir - Çelik sektörü, çok eski zamanlardan beri çeşitli sanayilerin gelişmesinde ve toplumların kalkınmasında büyük öneme sahip olagelmiştir. Özellikle gelişmekte olan ülkeler göz önüne alındığında Demir - Çelik sektörü, diğer sektörlere öncülük yapmış ve yapmaya devam etmektedir. Türkiye ve Dünya için önemli bir sektör olan Demir - Çelik sektörü, küresel ekonomide de, ülke ekonomisinde ve sanayileşmede lokomotif sektör özelliğine sahiptir.

Sektör, çelik ürünlerin kullanım alanının yaygınlaşması, her geçen gün tüketiminin artması, imalat sanayine ara mal üretilmesi ve ihracat potansiyeli gibi niteliklerinden dolayı ülke ekonomisi açısından büyük önem taşımaktadır [1].

Demir - Çelik sektörü, demir cevherinin yer altından çıkartılmasını takiben, yoğunlaştırılmasından başlamak üzere dökme, dövme, haddeleme, çekme ve benzeri yöntemler ile üretiminin gerçekleştirildiği bir sektördür [2]. Üretilen ürünlerin çeşitliliği göz önüne alındığında ise geleneksel sanayilerin yanı sıra teknolojik alanlarda da Demir - Çelik sektörünün öneminin giderek daha çok arttığı görülmektedir. Demir - Çelik üretiminde meydana gelen hızlı gelişmeler sonucunda endüstri devrimi gerçekleşmiş ve teknoloji alanında büyük gelişmeler yaşanmıştır.

Dünyadaki gelişmelerden en fazla etkilenen sektörlerin başında kuşkusuz Demir-Çelik sektörü gelmektedir. Tüm endüstriyel alanlarla en fazla bağlantısı olan sektörlerden biri olan Demir - Çelik sektöründe tarih boyunca meydana gelen gelişmeler, toplumların sosyoekonomik yapılarını şekillendirmede büyük rol oynamıştır. Demir - Çelik sektörü, sanayi toplumu sürecinin çekirdeğini oluşturan bir sektör olarak, bilgi toplumuna geçişle birlikte önemini korumuş, tüm endüstriyel dallara girdi temin etmesinden dolayı, imalat sanayi, dayanıklı tüketim ve yatırım malı sanayileri üzerinde belirleyici bir unsur olmuştur [3]. Üretilen ürünlerin çeşitliliği göz önüne alındığında ise geleneksel sanayilerin yanı sıra teknolojik alanlarda da, Demir - Çelik sektörünün öneminin giderek daha çok arttığı görülmektedir. Türk Demir - Çelik üreticilerinin yeni rekabet koşullarına uyum sağlamak adına uzun vadeli stratejiler geliştirmesini zorunlu kılmaktadır.

Dünya genelinde toplam ekonomik faaliyetlerin artması ile ülke ekonomilerindeki büyümenin bir yansıması olarak konuta olan ihtiyacın, otomobile olan talebin ve başta beyaz eşya olmak üzere diğer Demir - Çelik ürünleri talebinin her geçen gün büyük bir hızla artması, Dünya Çelik üretimini de artırmış ve arttırmaya devam etmektedir [4].

Demir - Çelik sektöründe üretilen ürünler ara mamuller, ana mamuller ve yan mamuller olmak üzere üç kısımda incelenir. Ara mamul başka bir malın üretiminde girdi olarak kullanılmak üzere üretilen ürünlerdir. Ana mamul bir başka işlem gerektirmeyen, nihai kullanım için üretilen ürünler olup yan mamuller ise üretim süreci sonunda teknik nedenlerle ana ürün ile beraber ortaya çıkan ürünlerdir.

Sektöre yönelik yarı mamul, yan mamul ve ana mamul çeşitleri Tablo 1'de gösterilmiştir: 
Tablo 1. Demir Çelik Sektöründe Üretilen Kategorize Edilmiş Mamuller [4]

\begin{tabular}{lc}
\hline \multicolumn{1}{c}{ MAMÜL CINSİ } & MAMÜL ÇEŞİDí \\
Kok, Kok Tozu, Kok Gazı, Oksijen, Ham Benzol, Pres Naftalin, Granüle & Yan mamul \\
Cüruf, Ham Katran, Kreozot, Zift ve Katran Boyası, Amonyum Sülfat & \\
Sıvı Ham Demir, Pik, Demir Pik (Kanal + Karışık Pik), Sıvı Çelik, & Ara mamul \\
Kütük, İngot, Blum & Ana mamul \\
Yuvarlaklar, Demir Yolları Malzemeleri (Ray), Maden Direği, Profil, \\
Köşebent, Platina
\end{tabular}

Ülkemizde ilk Demir - Çelik sanayisi kuruluş çalışmalarına 1932 yılında Kırıkkale’de savunma sanayisinin çelik ihtiyacını karşılamak amacıyla, Askeri Fabrikalar Müdürlüğü'ne bağlı fabrikanın kurulmasıyla başlanmıştır. Bu fabrikada her türlü takım çelikleri, makine yapı çelikleri ve az miktarda da olsa inşaat demirinin üretilmesiyle birlikte demir - çelik sanayisinin temel alt yapısı da oluşturulmaya başlanmıştır.

Birinci Dünya Savaşı ve Kurtuluş Savaşı sonrasında, ulusal bir Demir - Çelik sanayisine duyulan ihtiyacın sonucu olarak 1935 yılında Sümerbank'a bağlı Karabük Demir Çelik Fabrikaları kurulmuştur. Türkiye Cumhuriyeti’nde Demir cevheri üretimi, Karabük Demir Çelik Fabrikası'nın kurulmasıyla başlamıştır. Karabük Demir Çelik Fabrikası, maden kömürü havzasına yakın oluşu, demiryolu güzergâhına yakın olması ve jeopolitik bakımdan elverişli durumda bulunması nedeniyle, 3 Nisan 1937'de Karabük'te kurulmuş ve işletme üniteleri, 1 Haziran 1939 yılından itibaren, 150.000 ton çelik üretim kapasitesi ile faaliyete geçmiştir [3].

Ülkemizde ham çelikten nihai mamul üreten üreticiler Marmara, Ege, Akdeniz, Karadeniz ve İç Anadolu bölgesinde faaliyet göstermekte olup, üreticilerin çoğunluğu Marmara, Ege, Akdeniz sahil şeridinde yer almaktadır. Demir - Çelik sektöründe 2013 yılı itibariyle yaklaşık 150’ye yakın firma faaliyet göstermektedir. Bunların içerisinde kapasiteleri 50.000 ton ile 3.500.000 ton arasında değişen Elektrik Ark Ocaklı tesis ile toplam kapasiteleri 8.500.000 ton olan entegre tesis bulunmaktadır. Diğer tesisler ise sadece haddehane hüviyetinde olup, dışarıdan satın almış oldukları kütük ile profil, filmaşin, nervürlü ve yuvarlak inşaat demiri üreten tesislerdir. 2012 yılı itibari ile Türkiye Demir - Çelik kapasitesine ilişkin harita Şekil 1'de verilmiştir. 


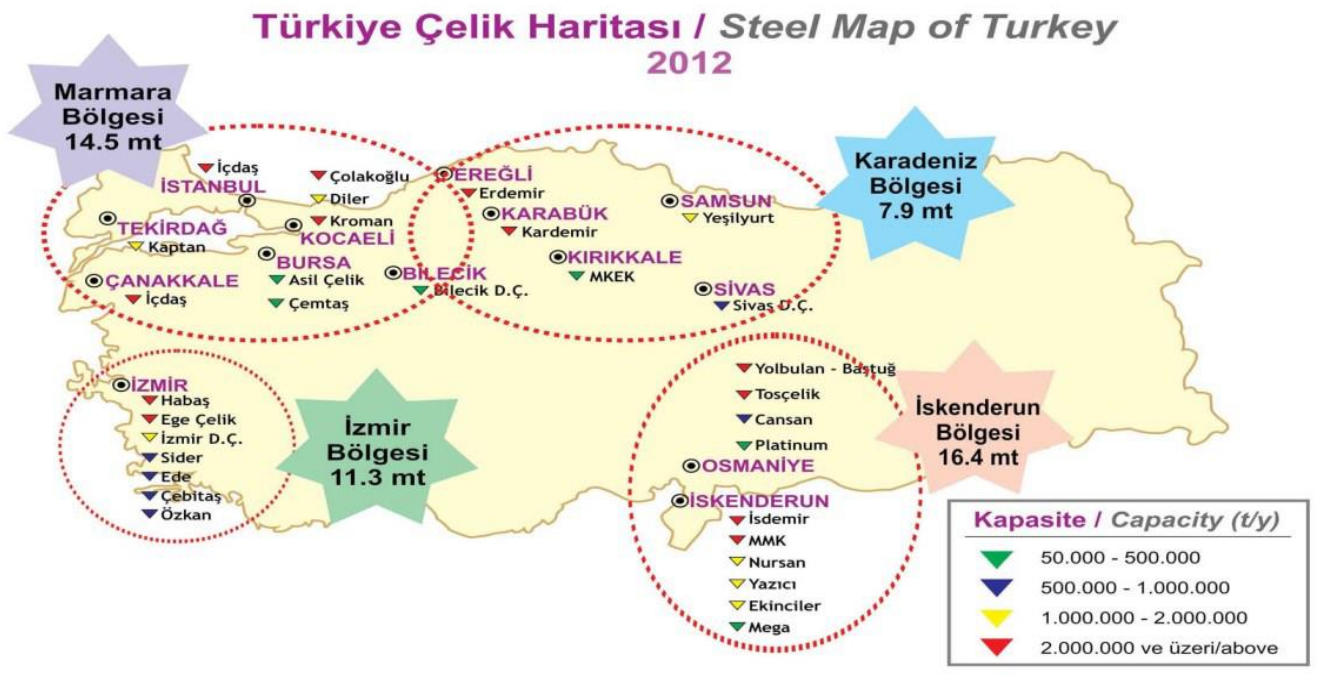

Şekil 1. Türkiye Çelik Haritası [6]

Türkiye'de ham çelik üretiminin \% 73,6'sı elektrikli ark ocaklarında (EAO) gerçekleştirilirken; \% 26,4'ü entegre tesislerde gerçekleştirilmektedir. 2010 yılında 29,1 milyon ton ile bu kapasitenin \% 59,7'si kullanılmıştır. 2010 yılı itibariyle nihai mamul üretimi 26,3 milyon ton iken; nihai mamul tüketimi 23,6 milyon ton olarak gerçekleşmiştir. Miktar olarak Demir-Çelik ürünlerinin ihracatı, 17,6 milyon ton olarak gerçekleşmiş olup, bu rakamın \% 52'sini uzun ürünler oluşturmaktadır. Miktar olarak Demir-Çelik ürünlerinin ithalatı ise 11 milyon ton civarında gerçekleşmiş olup, bu rakamın \% 62'sini sanayide büyük öneme sahip sac, levha ve kaplama ürünlerin ana kaynağı olan “yassı ürünler” oluşturmuş̧ur [2].

2012 yılı itibariyle üretimini \% 5,2 oranında artıran sektör, 2013 yılında Çin'deki rekor üretim ve ihracatın vermiş olduğu olumsuz etkiyle 2013 yılında 2012 yllına oranla \%3,4 oranında gerilemiştir. Yalnız bu dönemde de Dünya Çelik üretiminde ilk 8 üretici arasındaki yerini almıştır. Ham Çelik üretimine ilişkin bilgiler aşağıda Tablo 2 'de verilmiştir.

Tablo 2. Türkiye'nin Ürünlere ve Yöntemlere Göre Ham Çelik Üretimi (1000 ton) [7]

\begin{tabular}{lccccc}
\hline & $\mathbf{2 0 1 1}$ & $\mathbf{2 0 1 2}$ & $\mathbf{2 0 1 3}$ & $\begin{array}{c}\text { \% Değişim } \\
(\mathbf{1 2} / \mathbf{1 1})\end{array}$ & $\begin{array}{c}\text { \% Değişim } \\
\mathbf{( 1 3 / 1 2})\end{array}$ \\
Kütük & & & & 10.9 & -2.8 \\
Slab & 24400 & 27054 & 26294 & -9.0 & -5.3 \\
TOPLAM & $\mathbf{3 4 1 0 7}$ & $\mathbf{3 5 8 8 5}$ & $\mathbf{3 4 6 5 4}$ & & \\
EAO & 25275 & 26560 & 24723 & 5.08 & -6.9 \\
BOF & 8832 & 9.325 & 9931 & 5.08 & 6.4 \\
TOPLAM & $\mathbf{3 4 1 0 7}$ & $\mathbf{3 5 8 8 5}$ & $\mathbf{3 4 6 5 4}$ & $\mathbf{5 . 2}$ & $\mathbf{- 3 . 4}$ \\
\hline
\end{tabular}


Sektör, çelik ürünlerin kullanım alanının yaygınlaşması, her geçen gün tüketiminin artması, imalat sanayine ara mal üretilmesi ve ihracat potansiyeli gibi niteliklerinden dolayı ülke ekonomisi açısından büyük önem taşımaktadır[1].

Demir - Çelik sektöründe, başta inşaat ve otomotiv olmak üzere, boru, profil, dayanıklı tüketim eşyası, yakıt araç ve gereçleri imalatı, tarım araçları imalatı ve gemi inşa sektörüne yönelik üretim yapılmaktadır. İnşaat, otomotiv, makine ve metal eşya sektörlerinin, toplam Dünya Çelik tüketiminin \% 94'ünü gerçekleştirmesine rağmen, Çin gibi gelişmekte olan ülkelerde bu oranın AB gibi gelişmiş ülkelere kıyasla daha yüksek seviyelere çıkabildiği, benzer şekilde otomotiv endüstrisinin Almanya ve ABD'deki toplam çelik tüketiminin \% 20' sini gerçekleştirdiği, bu oranın Çin'de \% 3 seviyesinde kaldığ 1 belirtilmektedir [5].

Türk Demir - Çelik sektörü, 2011 yllında 34 milyon ton ham çelik üretimi ile endüstriyel sektörlerdeki toplam istihdamın \% 1'ineve 17 milyar dolarlık ihracat ile tüm sektörlerin toplam ihracatının \% 10'una sahip bulunmaktadır. Bu yönü ile sektör en çok ihracat yapan sektörler arasında yer almaktadır. Sektörün en önemli sorunlarından biri ağırlıklı olarak ithal girdiyle çalışması olup, Elektrik Ark Ocaklı (EAO) gibi kuruluşlarda hammadde olarak kullanılan hurdanın \% 70 civarındaki bölümü ithal edilmektedir. 2011 yılında 9,8 milyar dolarlık hurda ithal edilmiş ve bu ithalatın büyük bir kısmı ABD, Rusya, Ukrayna ve AB ülkelerinden yapılmıştır. Entegre tesislerde ise, hammadde olarak 1,1 milyar dolarlık (4 milyon ton) taş kömürü ve 1,2 milyar dolarlık demir cevheri ithal edilmiştir [6].

Dünya'da teknolojik yönden gelişmiş ülkeler, Demir-Çelik üretiminde, miktar olarak fazla üretim yapmaktansa; yassı, vasıflı, paslanmaz, kaplanmış veya daha özel, katma değeri yüksek çelik ürünlerin üretimine yönelmeye başlamışlardır. Buna karşılık, Türkiye de dâhil olmak üzere, gelişmekte olan ülkeler, miktar olarak fazla üretim yapma eğiliminde kalmışlardır. Bu nedenle, vasıflı çelik, paslanmaz çelik ve yassı ürünlerde üretim yapmak önem arz etmektedir. 2011 yılında, Demir-Çelik Sektörünün ülkemizin toplam ihracatı içerisindeki payının \% 10 olması sektörün ihracat potansiyelini göstermektedir [7].

Dünya Çelik Birliği'nin (World Steel Association) son verilerine göre AB'nin 27 üye ülkesi 2008 yılında toplamda yaklaşık olarak 1.33 milyar ton civarında olan küresel ham çelik üretiminin \% 15 'ine denk gelen miktarda (200 milyon ton) ham çelik üretmiştir. AB 2010 yllında 173 milyon ton ham çelik üreterek, Dünyadaki ikinci en büyük çelik üreticisi olmuştur [8].

Çelik üretiminin coğrafik dağılımına baktığımızda 1 milyar 414 milyon ton olan dünya ham çelik üretiminin çok büyük bir kısmının (\% 63,6) Asya kıtasında üretildiği görülmektedir. Asya'dan sonra en büyük pay \% 14,60 ile Avrupa'ya ait olup, bu rakamın \% 2'si ise Türkiye'ye aittir [9].

Dünya ham çelik ürünleri üretiminin ülkelere göre dağılımı Tablo 3 ve Şekil 2'de gösterilmiştir. 
Ersöz T., Düğenci M., Ünver M., Eyiol B.

Tablo 3.Dünya Ham Çelik Üretimi (Bin Ton) [8]

\begin{tabular}{llll}
\hline & $\mathbf{2 0 1 1}$ & $\mathbf{2 0 1 2}$ & \% Değişim \\
AB(27 Ülke) & 117,431 & 169,43 & $-4,51 \%$ \\
Diğer Avrupa Ülkeleri & 37,181 & 37,86 & $1,83 \%$ \\
B.D.T & 112,434 & 111,177 & $-1,12 \%$ \\
Kuzey Amerika & 118,927 & 121,863 & $2,47 \%$ \\
Güney Amerika & 48,357 & 46,931 & $-2,95 \%$ \\
Afrika, Orta Doğu & 34,291 & 34,447 & $0,45 \%$ \\
Asya & 954,19 & 982,711 & $2,99 \%$ \\
Okyanusya & 7,248 & 5,805 & $-19,91 \%$ \\
Dünya (62 Ülke) & 1.490 .060 & 1.510 .223 & $1,35 \%$ \\
\hline
\end{tabular}

2010 yılı itibariyle tüm Avrupa ülkelerinin Dünya ham çelik üretimindeki pazar payı \% 14,6'dır.

Türkiye \% 2,1'lik pazar payı ile Almanya'nın ardından Avrupa'daki en büyük ikinci ham çelik üreticisi konumundadır. Almanya 2009 krizi sebebiyle yaklaşık 11 milyon ton üretim daralması yaşamıştır ve 2010 yılında kriz öncesi dönemdeki üretim miktarının altında kalmıştır. Türkiye ise kriz döneminde yaklaşık 1,5 milyon ton üretim daralması yaşamış ancak 2010 yılında hemen toparlanarak üretimini 2007 y1lına göre yaklaşık 3,5 milyon ton artırmıştır. Avrupa'da Türkiye'den sonraki en büyük çelik üreticisi \% 1,8'lik 2010 yılı pazar payı ile İtalya'dır [10].

Demir-Çelik tüketiminin sektörlere göre dağılımı Şekil 2'deverilmiştir. Hemen hemen tüm ülkelerde inşaat sektörü, Demir - Çelik sektörünün en büyük müşterisidir. Daha sonra ise otomotiv ve makine sanayi gelmektedir. Bu sektörlerin önümüzdeki yıllardaki performansları Demir-Çelik sektörünün performansını çok ciddi şekilde etkileyeceği belirtilmiştir [11].

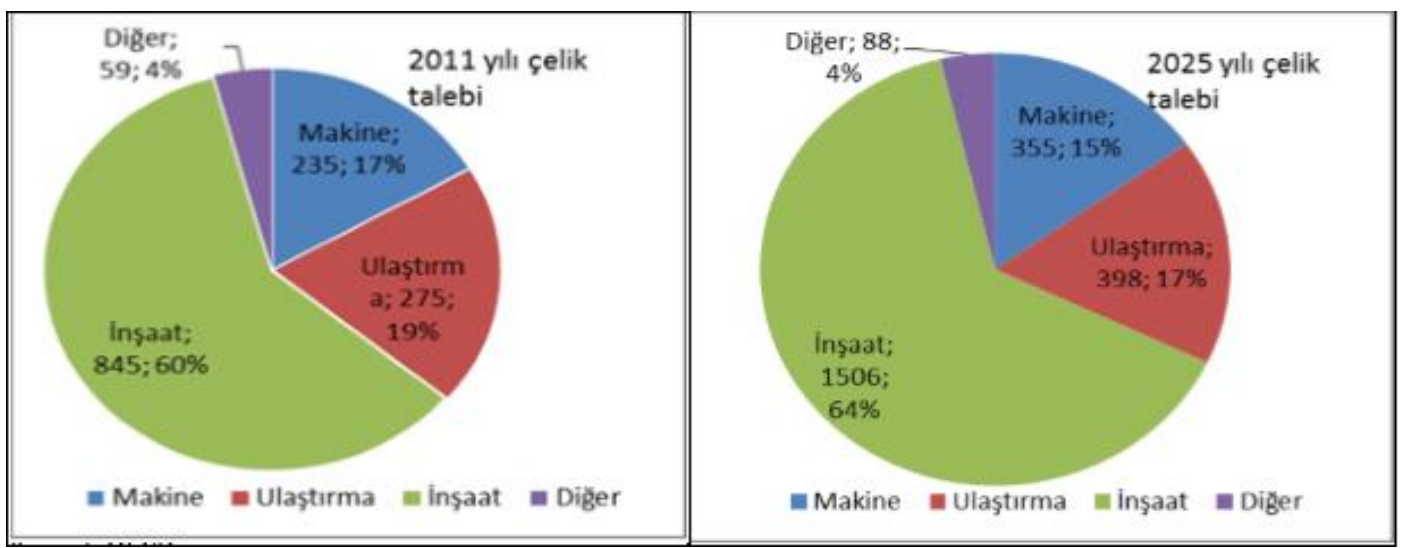

Şekil 2. Sektörlere Göre Demir - Çelik Tüketimi (\%) [9]

Türkiye'nin nihai ürün üretiminin büyük bölümü (\% 75) uzun ürün üretimidir. Dolayısıyla en büyük Demir - Çelik ihracat kalemimiz \% 52'lik pay ile uzun ürünlerdir. Demir - Çelik ürünleri içinde en 
önemli ihracat kalemimiz olan uzun ürünlerde 2007 yllında $\mathrm{AB}$ ülkeleri \% 33’lük ihracat oranı ile önemli bir müşterimiz iken 2010 yılında uzun ürün ihracatımızın sadece \% 6's1 AB ülkelerine yapılmıştır. Miktar olarak azalış 3 milyon tonun üzerindedir. Uzun ürün açısından Türkiye'nin en önemli müssterileri y1llardan beri ortalama \% 50’lik payla Orta Doğu ve Körfez ülkeleridir [12].

Türkiye, AB’ye, başlıca olarak, yarı bitmiş veya uzun ürünler ihraç etmektedir. Buna rağmen, Türkiye AB'den yüksek değere sahip yassı ve özel çelik ürünleri ithal etmektedir. Türkiye'nin en fazla Çelik ihracatı yaptığı üçüncü yer Avrupa Birliği olup, Türkiye 2010 yılında Avrupa Birliği’ne 17.3 milyon ton çelik ihraç etmiştir[8].

Yassı ürünler ve vasıflı çelik ürünlerin entegre tesislerde üretilebilmesi, uzun ürünlerin ise elektrik ark ocaklı tesislerde üretilebilmesi dolayısıyla, entegre tesislerin ağırlıkta bulunduğu ülkeler katma değeri yüksek olan yassı ürünlerin ve vasıflı çelik ürünlerinin ihracatçısı konumunda iken, üretimin çoğunluğunu elektrik ark ocaklı tesislerde gerçekleştiren ülkeler ise bu ürünlerin ithalatçısı konumundadır [13]. Demir çelik sektörünü ihracat ve ithalat bazında değerlendirdiğimizde ise ortaya şöyle bir tablo çıkmıştı:

2010 yılındaki en büyük çelik ihracatçısı ülkeler arasında;

- Japonya, 42,7 milyon ton ve $\% 11,0$ pay ile ilk sirada,

- Çin Halk Cumhuriyeti 41,6 milyon ton ve \% 10,8 pay ile ikinci sırada,

- $\quad$ Rusya 27,4 milyon ton ve \% 7,1 pay ile üçüncü sirada,

- $\quad$ Türkiye 17,6 milyon ton ve \% 4,6 pay ile 7 . sırada yer almıştır.

Dünya Çelik ürünleri toplam ithalat hacmi ise 2000 yılından 2009 yılına kadar sürekli bir artış göstermiş̧ir. 2009 yılında dünya yarı ve nihai çelik ürünleri ithalatı, 2008 yılına göre $\% 24$ oranında azalışla, 321 milyon ton olarak gerçekleşmiştir. Bu değer 2003 yılındaki 332 milyon tonluk ithalat hacminin dahi altındadır [14].

2010 yılında, Demir - Çelik ürünleri ithalatında, Güney Kore, 24,8 milyon ton ve \% 6,6 pay ile ilk sırada, Almanya 22,7 milyon ton ve $\% 6,0$ pay ile ikinci sırada, ABD 22,5 milyon ton ve $\% 6,0$ pay ile üçüncü sırada yer alırken, Türkiye 11,0 milyon ton ve \% 2,9 pay ile 9. sırada yer almıştır [15].

Son veriler, Demir - Çelik ürünlerinde ithalat baskısının yılın ikinci çeyreğinde de devam ettiğini göstermektedir. Yllın ikinci çeyreğinde, aylık ortalama 3,1 milyon ton seviyesinde gerçekleşen üçüncü ülkelerden yapılan ithalat, son üç yıldan bu yana en yüksek seviyesine ulaşmıştır. 2010 yılının tamamında \% 16 seviyesinde bulunan ithal ürünlerin $\mathrm{AB}$ çelik piyasasındaki payı, 2011 yılının ikinci çeyreğinde \% 21 seviyesine yükselmiştir. 2011 yılının Ocak - Ağustos döneminde, özellikle yassı ürünlerin ithalatında büyük artışlar yaşanmıştır. 2011 yılının ilk sekiz aylık döneminde, toplam yassı ürün ithalatında \% 51, toplam uzun ürün ithalatında \% 21 oranında artış yaşanmıştır. Uzun ürünlerde, filmaşin ve nervürlü demir ithalatında düşüş yaşanırken, ticari çubuk ithalatında büyük bir artış gözlenmişstir. En fazla çelik ürünleri ithalatının yapıldığı ülke ise Çin Halk Cumhuriyeti olmuştur [11].

1995 ’ten itibaren yassı çelik sektörü ihracatı dalgalı bir seyir izlemiştir. 2001 yılında yassı ürün ihracat1 1.088.187 ton iken 2002 y1lında 755.6441 tona düşmüştür. 2005 y1lında 1.188 .000 bin tona, 2010 yılında ise 1.519 .000 bin tona yükselmiştir. Yıllara göre Demir -Çelik ihracat değerleri ve değişimi Tablo 4 'de verilmiştir. 
Ersöz T., Düğenci M., Ünver M., Eyiol B.

Tablo 4. Yıllara Göre Demir Çelik İhracatı (Milyon \$) [7]

\begin{tabular}{|c|c|c|c|c|c|c|}
\hline & & İhracat & & & İthalat & \\
\hline & 2011 & 2012 & \% değișim & 2011 & 2012 & \% değişim \\
\hline Yarımamülürünler & 763.197 .881 & 856.727 .826 & 12,26 & 715.984 .952 & 849.282 .738 & 18,62 \\
\hline Yassı ürünler & 1.101 .169 .431 & 766.908 .857 & $-30,36$ & 3.129.177.996 & 2.875.109.319 & $-8,12$ \\
\hline Uzun ürünler & 3.529 .843 .914 & 4.175 .872 .733 & 18,30 & 711.920 .571 & 693.661 .231 & $-2,56$ \\
\hline Çelik ürünleri toplamı & 5.394 .211 .226 & 5.799 .509 .416 & 7,51 & 4.557 .083 .519 & 4.418 .053 .288 & $-3,05$ \\
\hline Borular & 830.749 .074 & 822.791 .773 & $-0,96$ & 318.382 .615 & 295.102 .460 & $-7,31$ \\
\hline
\end{tabular}

Sektörün ihracatı ürün bazında yukarıdaki Tablo 3'den de görüleceği üzere, 2012 yılında, 2011 yılı 6 aylık verilerine kıyasla, yassı ürün ihracatı değer bazında $\% 30$ oranında azalma gösterirken, geçen yılın aynı dönemindeki 1,10 milyar Dolar seviyesinden, 766,9 milyon dolara gerilemiştir. Diğer taraftan, bu yıl temmuz ayı itibariyle, Türkiye'nin toplam yassı ürün ithalatı değer bazında, $\% 8$ oranında azalışla 3,1 milyar dolardan 2,8 milyar dolara gerilemiştir.

Türkiye'nin, 2015 yılına kadar, yassı-uzun ürün arz-talep dengesizliğinden kaynaklanan sorunları önemli ölçüde geride bırakması ve Demir- Çelik sektörünün ödemeler dengesi açığını kapatma yönünde önemli katkı sağlaması beklenmektedir. 2012 yılı itibariyle, sektör yassı ürünlerdeki tüketimi karşılayacak kapasitededir, ancak yüksek ithalat oranları dikkat çekmektedir. Demir Çelik Sektöründe önemli ihracatçı ülkeler aşağıda Tablo 5 'te verilmişsir. 
Tablo 5. Demir - Çelik Sektöründe Önemli İhracatçı Ülkeler (2012) [7]

\begin{tabular}{|c|c|c|}
\hline Sira & Ülke & İhracat (Milyon Ton) \\
\hline 1. & Çin & 54,793 \\
\hline 2. & Japonya & 41,458 \\
\hline 3. & Güney Kore & 30,227 \\
\hline 4. & Rusya & 26,678 \\
\hline 5. & Almanya & 25,818 \\
\hline 6. & Ukrayna & 24,142 \\
\hline 7. & Türkiye & 18,664 \\
\hline 8. & İtalya & 17,926 \\
\hline 9. & Fransa & 14,579 \\
\hline 10. & Belçika & 14,456 \\
\hline 11. & $\mathrm{ABD}$ & 13,560 \\
\hline 12. & Tayvan & 10,539 \\
\hline 13. & Hollanda & 9,734 \\
\hline 14. & Brezilya & 9,704 \\
\hline 15. & İspanya & 9,416 \\
\hline 16. & Hindistan & 8,232 \\
\hline 17. & İngiltere & 6,410 \\
\hline 18. & Avusturya & 6,358 \\
\hline 19. & Kanada & 6,165 \\
\hline
\end{tabular}

Tablo 5 'te Dünyanın en büyük beş çelik ihracatçısı ülkesi Çin, Japonya, Güney Kore, Rusya ve Almanya'dır. Bu ülkelerin ihracatı toplam dünya ihracatının yarısını aşmaktadır. 2012 yılında, 54,793 milyon tonla Çin, dünyanın en fazla Demir - Çelik ihracatı yapan ülkesi olmuştur. Çin'i41,458 milyon ton ile Japonya, 30,227 milyon ton ile Güney Kore, 26,678 milyon ton ile Rusya ve25,818 milyon ton ile Almanya takip etmektedir. Türkiye 2012 yılında gerçekleştirdiği 18,664 milyon tonluk ihracatı ile dünya sıralamasında 7. sırada yer almıştır.

Tüketim açısından bakıldığında Dünya -Çelik tüketimi 2011 yılında 1380,9 milyon ton olurken 2012 yılında 1409,4 milyon ton olması beklenmektedir. Diğer taraftan, OECD uzmanlarının 2012 ve 2013 yılına ait bölgesel olarak tüketim tahminleri aşağıdaki tablo 6'da verilmiştir.

Tablo 6. Bölgesel Çelik Tüketim Miktarları (Nihai Mamul) (OECD) [8]

\begin{tabular}{|c|c|c|c|c|c|c|}
\hline & \multicolumn{3}{|c|}{ Milyon ton } & \multicolumn{3}{|c|}{$\%$} \\
\hline & 2011 & $2012^{*}$ & $2013^{*}$ & $11 / 10$ & $12 / 11$ & $13 / 12$ \\
\hline Dünya & $1.380,9$ & $1.409,4$ & $1.454,9$ & 6,2 & 2,1 & 3,2 \\
\hline$A B(27)$ & 153,1 & 144,5 & 148,1 & 5,9 & $-5,6$ & 2,4 \\
\hline Diğer Avrupa & 33,2 & 34,4 & 36,0 & 12,7 & 3,8 & 4,5 \\
\hline CIS & 54,8 & 55,2 & 57,4 & 13,8 & 0,8 & 3,9 \\
\hline NAFTA & 121,3 & 130,4 & 135,1 & 9,0 & 7,5 & 3,6 \\
\hline $\begin{array}{l}\text { Merkez ve Güney } \\
\text { Amerika }\end{array}$ & 45,7 & 47,4 & 50,4 & 2,6 & 3,8 & 6,3 \\
\hline Afrika & 23,9 & 25,3 & 27,3 & $-3,4$ & 5,8 & 7,7 \\
\hline Orta Doğu & 48,2 & 49,9 & 52,8 & 2,9 & 3,5 & 5,9 \\
\hline Asya ve Okyanusya & 900,6 & 922,2 & 947,9 & 5,9 & 2,4 & 2,8 \\
\hline Çin & 623,9 & 639,5 & 659,2 & 6,2 & 2,5 & 3,1 \\
\hline
\end{tabular}

*2013 yll için beklenen tüketim miktarlarını ifade etmektedir. 
Gelişmiş ülkelerde çelik talebinin bir önceki yıla göre \% 0,3 azalması beklenirken, gelişmekte olan büyüyen ekonomilerde \% 3 artması öngörülmüştür. 2013 yılında ise Çin dışında Dünya tüketiminin $\% 3$ artması beklenmektedir.

Tablo 7. Küresel Çelik Talebi (OECD)* [8]

\begin{tabular}{|c|c|c|c|c|c|c|}
\hline & \multicolumn{3}{|c|}{ Milyon Ton } & \multicolumn{3}{|c|}{$\%$} \\
\hline & 2011 & $2012^{*}$ & $2013^{*}$ & $11 / 10$ & $12 / 11$ & $13 / 12$ \\
\hline Dünya & $1.380,9$ & $1.409,4$ & $1.454,9$ & 6,2 & 2,1 & 3,2 \\
\hline Çin hariç Dünya & 757,0 & 769,9 & 795,6 & 6,3 & 1,7 & 3,3 \\
\hline Gelişmiş Ülkeler & 395,6 & 394,6 & 402,1 & 6,2 & $-0,3$ & 1,9 \\
\hline $\begin{array}{l}\text { Gelişmekte Olan } \\
\text { Ülkeler }\end{array}$ & 985,2 & 1014,8 & 1052,8 & 6,3 & 3,0 & 3,7 \\
\hline $\begin{array}{l}\text { Çin hariç Gelişmekte } \\
\text { Olan Ülkeler }\end{array}$ & 361,4 & 375,3 & 393,5 & 6,4 & 3,9 & 4,9 \\
\hline
\end{tabular}

*2013 yılı için beklenen tüketim miktarların ifade etmektedir.

Demir - Çelik sektörüne yönelik yapılan bilimsel çalışmalar incelenecek olursa, Ordu’nun tez çalışmasında; Demir - Çelik sektörü ile Demir - Çelik sektöründe üretimi yapılan ve uzun ürünler olarak nitelendirilen ürün grubu incelenmiştir. Ayrıca veri madenciliği tekniklerini kullanarak uzun ürün grubu ilgili olarak; uzun ürünlerin üretimine ilişkin değişkenler incelenmiş ve veri madenciliğinde sınıflandırma temelli teknikler kullanılarak yapılan analizler ile Demir - Çelik üretim miktarına ilişkin tahmin modeli ve üretimi etkileyen en önemli değişkenler bulunmuştur. Çalışmada, öncelikle Demir - Çelik sektörü hakkında bilgiler verilerek veri madenciliği (VM), veri madenciliğinin tarihsel gelişimi, bileşenleri, sınıflamaları, kullanım alanları, farklı alanlarda geliştirilen VM uygulamalarında kullanılan sınıflandırma temelli modeller incelenmiştir. Tez çalışmasında, Başbakanlık Yüksek Denetleme Kurumu (BYDK)'ndan elde edilen uzun hadde ürünlerinin 1943-1994 yılları arasındaki üretim verilerine, Veri Madenciliği yöntemleri (Çoklu Regresyon Analizi, Karar Ăgacı Analizi) uygulanmıştır. Elde edilen bilgiler doğrultusunda üretim temelli modeller oluşturularak, çalışma sonuçlarının ileriye dönük alınacak yatırım kararlarına ışık tutması hedeflenmiştir [16].

Birleşik Metal İşçileri Sendikasının çalışmasında; Dünya'da ve Türkiye'de Demir Çelik sektöründeki gelişmelerin incelenmesini, diğer sektörleri izlemek açısından olduğu kadar, ilerde yaşanabilecek ciddi sorunları ve bedellerini öngörebilmek, sektöre ilişkin güncel bilgilerin derlenmesi ve benzeri sorunlar yaşayan diğer ülkelerin sektördeki sendikal örgütleriyle uluslararası bilgi alışverişinin geliştirebilmek için de bu alanda araştırmalar yapılmasını gerektirdiği tespit edilmiştir [17].

Koca'nın tez çalışmasında; Dünyadaki gelişmelerin ışığında, Türk Demir - Çelik sanayiinin gelişimi değerlendirilmiş ve Porter'ın “Sektörlerin Yapısal Analizi” yaklaşımı kullanılarak sektörün uzun vadede rekabet edebilirliğini sürdürmeye yönelik strateji önerileri geliştirilmiştir. Çalışmada, literatür taraması, istatistiki veri derleme ve veri inceleme yöntemleri kullanılmıştır [18].

Atgür'ün çalışmasında; Avrupa Birliği'ne uyum sürecindeki Türk Demir - Çelik sektörünün analizi yapılarak, sektörün sorunları tartışılmakta ve çözüm önerileri ortaya konulmuştur. Bu amaçla 
öncelikle Demir - Çelik ile ilgili kavramlar tanımlanarak, sektörün Dünyadaki gelişimi ve mevcut durumu incelenmiştir. Elde edilen bulgular, sanayi üretiminden Demir - Çelik üretimine doğru kısa ve uzun dönemde olmak üzere tek yönlü bir ilişkinin varlığını ortaya koymuştur [3].

Yıldırım ve diğerlerinin çalışmasında; ilk olarak Karabük ilinde Demir - Çelik sektöründe faaliyet gösteren üretim işletmelerinin mevcut durumlarını incelemiştir. İkinci olarak ise, bu işletmelerin rekabet güçleri ve rekabet güçlerini etkileyen faktörlerin neler olduğu ortaya çıkarılmıştır [19].

Öztürk ve Fındık'ın çalışmasında; Türk Demir - Çelik sektörünün gelişimi değerlendirilerek, Michael Porter tarafindan geliştirilen "Sektörlerin Yapısal Analizi” yaklaşımı kullanılarak, sektörün uzun vadede rekabet edilebilirliğini sürdürmeye yönelik strateji önerileri geliştirilmiştir [20].

Genel olarak Demir -Çelik Sektörünü analiz etmek konusunda, yüksek tonajda ürünlerin üretimi ve ticaretini yapan ülke ve bölgelerin değerlendirilmesi, geçmiş yıllardaki konumları ve günümüzdeki ve gelecekteki pozisyonlarını incelemek faydalı olacaktır. Bunu bilimsel bir yaklaşım dahilinde sağlamak üzere istatistiki analizlerden biri olan kümeleme analizi yaklaşımı demir-çelik üretimi, ithalatı ve ihracatı açısından dünyadaki gelişmeleri gözlemlemek ve yapılabilir politikaları gözden geçirmek konusunda değerli bir kaynak sunacaktır. Uygulamaya ilişkin materyal ve uygulama yöntemine ilişkin bilgiler ikinci kısımda verilmiş olup, edinilen bulgular, sonuçlar ve öneriler sırasıyla üçüncü ve dördüncü kısımlarda sunulmuştur.

\section{Materyal ve Metot}

Çalışmada, 5 milyon ton ve üzeri Demir-Çelik ürünü ihraç eden ülkelerin 2003-2012 yıllarında yapmış oldukları ihracat rakamları kullanılmıştır. Analizde her yıl Dünya Çelik Kurumu; "World Steel Assocoiation" tarafindan yayınlanan, İstatistiksel Çelik Yıllıkları; "Steel Statistical Yearbook" verileri kullanılmıştır. Çalışmada, Avrupa inovasyon göstergeleri kullanılarak, ülkelerin benzerlik ve farklılıklarını incelemek için, çok değişkenli istatistik tekniklerinden aşamalı (hiyerarşik) Kümeleme Analizi uygulanmıştır.Analiz ile;5 milyon ton ve üzeri ihracat yapan ülkelerin ihracat rakamları alınarak ülkelerin Hiyerarşik Kümeleme Analizi ile nasıl gruplandığına bakılmış ve buna bağlı olarak sonuçlara ulaşılmıştır.

Kümeleme analizi, nesneleri küme içerisinde çok benzer biçimde, kümeler arasında farklı olacak biçimde kümeler. Kümeleme işlemi başarılı olursa, bir geometrik çizim yapıldığında nesneler küme içerisinde birbirine çok yakın, kümeler ise birbirinden uzak olacaktır [21].

Kümeleme analizi bir gözlemler setini grup veya kümelerin sınırlı bir sayısına ayırmayı amaçlayan çok değişkenli bir istatistik yöntemdir. Ayırma, aynı gruptaki gözlemler birbirine benzer iken farklı gruplardaki gözlemler birbirinden farklı olacak şekilde yapılmaktadır [22].

Kümeleme yönteminin hesaplamaları oldukça hızlı olmasına karşın, hiyerarşik yöntemler çok büyük örnekleri analiz etmede uygun değildir [22]. Bu çalışmada da incelenen örneğin az sayıda olmasından dolayı birbirine benzer ülke gruplarını belirleyebilmek amacıyla hiyerarşik kümeleme analizine başvurulmuştur. Birimlerin sınıflandırılmasında sıklıkla kullanılan bir yöntem olması nedeniyle de kareli Öklid uzaklık (Squared euclidean distance) benzerlik ölçüsü olarak alınmıştır. Hiyerarşik kümeleme analizinde kümeleri birleştirebilmek amacıyla birçok bağlantı yöntemi (linkage method) bulunmaktadır. Her bir kümeleme yönteminin aynı veri setine uygulanması sonucu faklı kümeleme 
sonuçlarına ulaşılabilmesi nedeniyle en uygun ve güçlü tek bir yöntemin seçilmesi gereği açıktır. Bunu sağlamak için sadece tek bir yöntem keyfi olarak seçilmek yerine elde edilen sonuçların tutarlılığını pekiştirmek amacıyla tüm yöntemlerin denenmesi uygun görülmüş ve ortalama bağlantı (average linkage) yönteminin seçilmesine karar verilmiştir.

Kümeleme analizinde verilerin normal dağılımlı olması gerektiği varsayımı olmakla birlikte normallik varsayımı prensipte kalmakta, uzaklık değerlerinin normalliği yeterli görülmektedir. Ayrıca kümeleme analizinde kovaryans matrisine ilişkin herhangi bir varsayım bulunmamaktadır. Kümeleme analizi, temel olarak dört değiş̧ik amaç için uygulanır. Bu amaçlar aşağıdaki gibi sıralanabilir:

- $\quad \mathrm{n}$ sayıda birimi, nesneyi, oluşumu, p değişkene göre saptanan özelliklerine göre olabildiğince kendi içinde türdeş ve kendi aralarında farklı alt gruplara ayırmak,

- $\quad$ p sayıda değişkeni $\mathrm{n}$ sayıda birimde saptanan değerlere göre ortak özellikleri açıladığı varsayılan alt kümelere ayırmak ve ortak faktör yapıları ortaya koymak,

- $\quad$ Hem birimleri hem de değişkenleri birlikte ele alarak ortak $\mathrm{n}$ birime $\mathrm{p}$ değişkene gören ortak özellikli alt kümelere ayırmak,

- $\quad$ Birimleri, $\mathrm{p}$ değişkene göre saptanan değerlere göre, izledikleri biyolojik ve tipolojik sınıflamayı ortaya koymaktır [23].

Kümeleme analizi yardımıyla ülkelerin hangi sınıflara kümelendiği ve küme sayısı belirleme işlemi de dendogram yardımıyla yapılmıştır. Dendogram kümeleme analizi sonuçlarının grafik bir özetidir. Dikey eksende ülkeler kısaltmaları ile birlikte listelenmiștir. Yatay eksen ise kümeler arasındaki uzaklıkları göstermektedir. Böyle bir sınıflandırma ağacı yardımıyla küme sayılarının belirlenmesinde subjektif olarak belirlenmektedir.

\section{Bulgular}

5 milyon ton ve üzeri ihracat yapan ülkelerin ihracat rakamları alınarak ülkelerin Hiyerarşik Kümeleme Analizi ile nasıl gruplandığına bakılmış ve buna bağlı olarak sonuçlara ulaşılmıştır. Öncelikli olarak ihracat tonaj verilerinin minimum ve maksimum değerleri ile beraber ortalama ve standart sapmalarına ilişkin tanımlayıcı istatistikler hesaplanmıştır. Çalışmaya ilişkin tanımlayıcı istatistikler aşağıda Tablo 6 'da verilmiştir.

Tablo 8.Yıllara göre İhracat-Ton Bilgilerine ait Tanımlayıcı İstatistikler

\begin{tabular}{lrrrr}
\hline Yillar & Ortalama & \multicolumn{1}{c}{ Minimum } & Maksimum & Standart Sapma \\
2003 & 13655,421 & 5069,000 & 33728,000 & 8683,183 \\
2004 & 15171,052 & 5392,000 & 34768,000 & 9220,903 \\
2005 & 15477,263 & 5970,000 & 32040,000 & 8984,858 \\
2006 & 17816,578 & 6135,000 & 51706,000 & 12443,215 \\
2007 & 19122,894 & 6590,000 & 66357,000 & 14619,566 \\
2008 & 18697,105 & 7153,000 & 56304,000 & 12698,326 \\
2009 & 14245,368 & 4947,000 & 33306,000 & 8456,768 \\
2010 & 17037,947 & 6044,000 & 42735,000 & 11253,089 \\
2011 & 18031,421 & 6027,000 & 47899,000 & 11681,714
\end{tabular}


Tablo 6'da görüldüğü gibi 5 milyon ton ve üzeri Demir-Çelik ürünü ihraç eden ülkelerin 2003 2012 yıllarına bakıldığında 2009 yılında ihracatın düştüğü ve 2007 yılında ise en yüksek ihraç miktarına ulaşılmıştır.

Hiyerarşik Kümelemede örneklem sayısı 250 den küçük olmalıdır $(\mathrm{n} \leq 250)$. Hiyerarşik kümeleme analizi yapmak için araştırmacılar, benzerlik ya da uzaklığın nasıl tanımlanacağına ve kümelerin nasıl birleşeceğine ya da ayrılacağına karar vermek durumundadırlar. Hiyerarşik kümeleme yöntemlerinin, araştırmacının incelediği veri setinde kaç grup bulunduğunu başlangıçta bilmediği durumlarda çok uygun bir yöntem olduğunu belirtilmektedir. Ayrıca bu yöntemin araştırmacılara, inceledikleri veri setinde daha önce gözlemlenmemiş ilişkileri gözleme ve ilkeleri keşfetme olanağı vermesi nedeniyle de faydalı olduğunu belirtmektedir.

Ele alınan veri sayısı 250 den küçük olduğu için $(19<250)$ ve standart sapmanın çok büyük olmasından ve küme sayısının belli olmamasından dolayı uygulama hiyerarşik kümeleme yöntemiyle yapılmıştır. Uygulamada ülkelerin yıllara göre nasıl kümelendiği ve küme sayısının bulunması amaçlanmıștır.

K-Ortalamalar Kümeleme yönteminin uygulanmasında küme sayısını belirlemek için "Aşamalı kümeleme yöntemlerinden elde edilen dendogramları inceleyerek karar vermek" yaklaşımı seçilmiştir. Ülkelerinin ihracat miktarlarına ilişkin aşamalı kümeleme analizi yapılmış, "Kareli Öklit Uzaklığı" ve "Ward Yöntemi” kullanılmıştır. Şekil 3’te grafik bir sunum olan dendogram kümeleme sonuçları verilmiştir. 


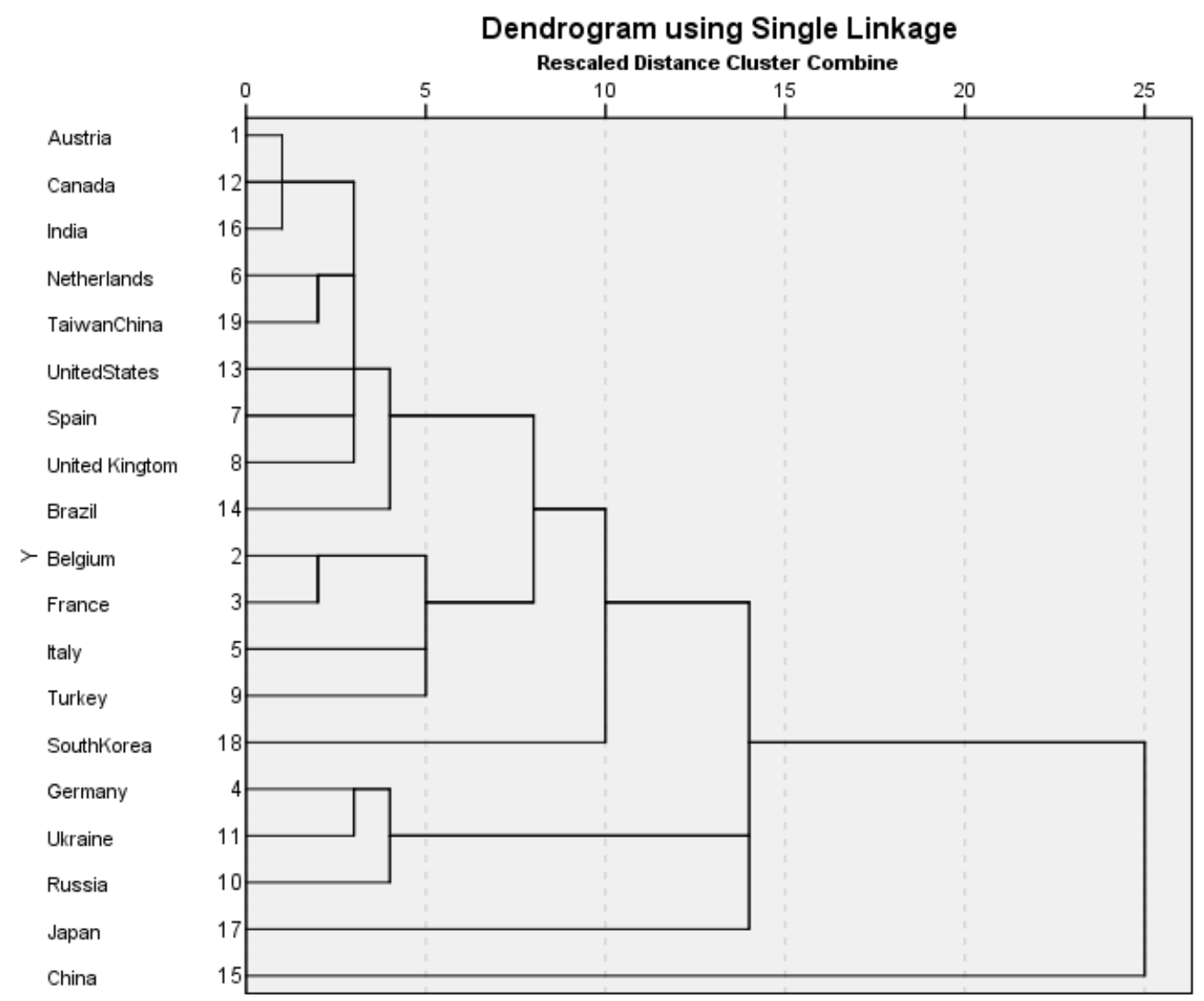

Şekil 3.Demir-Çelik Ürünü İhraç Eden Ülkelerin İhracat Rakamları Göstergesine Ait Dendogram

Dendogram, yaklaşık 15-20 arası mesafede 3 ve 7-12 arası mesafede ise 5 kümeye işaret etmektedir. Aşamalı küme yöntemi sonucunda oluşan küme sayısı sonucuna göre, ülkelerin 5 grupta oluştuğu görülmüştür. Buna göre ülkeleri 5 grup içerisinde ele almak gerekmektedir.

Tablo 7, küme oluşumlarını ve Türkiye'nin Dünya ülkeleri arasındaki kareli Öklid uzaklıklarını göstermektedir.

Tablo 9. Beş Milyon Ton Üzeri Demir-Çelik İhraç Eden Ülkelerin Küme Üyelikleri

\begin{tabular}{cl}
\hline Küme No & \multicolumn{1}{c}{ Küme Elemanları } \\
1 & Avusturya, Kanada, Hindistan \\
2 & Hollanda, Tayvan (Çin) \\
3 & ABD, İngiltere, İspanya, Brezilya \\
4 & Türkiye, Belçika, Fransa, İtalya \\
5 & Almanya, Ukrayna, Rusya \\
\hline
\end{tabular}

Türkiye'nin Demir-Çelik ürünü ihracatı açısından, Şekil 3'e göre oluşturulan Tablo 9'a bakıldığında, Dünya ülkeleri içerisindeki konumu incelenirse; İtalya, Fransa, Belçika ile aynı kümede yer aldığı görülmüştür. Çin, Japonya ve Güney Kore’nin en yakın kümelemede aynı kümede yer almadığı görülmüştür. 


\section{Sonuç ve Öneriler}

Bu çalışmada, 5 milyon ton ve üzeri Demir-Çelik ürünü ihraç eden ülkelerin 2003 - 2012 yıllarında yapmış oldukları ihracat rakamları kullanılmıştır. Yapılan aşamalı kümeleme yöntemi sonucunda oluşan küme sayısı sonucuna göre, ülkelerin 5 grupta oluştuğu görülmüştür. Çin, Japonya ve Güney Kore’nin en yakın kümelemede bir kümede yer almadığı görülmüştür.

Analiz sonuçlarını incelediğimizde; Dünya çelik üretiminin yaklaşık yarısını gerçekleştiren Çin, Dünya'nın en büyük çelik üreticisidir. Aynı zamanda Dünya'nın en büyük çelik üreticisi konumundadır. Son yıllarda en yüksek hızla büyüyen ekonomiye sahip olan Çin, diğer tüm sektörlerde olduğu gibi çelik sektöründe de belirleyici konumundadır. Çin, gerek çelik üretimi ve tüketimi gerekse çelik ihracatı ve ithalatında açık ara ilk sırada yer almaktadır. Japonya ve Güney Kore, Dünya çelik üretimi sıralamasında Çin'i ardından gelen ülkelerdir.

Türkiye benzer küme olarak, İtalya, Fransa ve Belçika ile aynı kümede yer almıştır. Göreceli olarak katma değeri yüksek çelik ürünler ihraç eden ülkelerdir. Brezilya ve İspanya gibi ülkeler katma değeri yüksek çelik ürünler ihraç eden ülkelerdir. Demir cevheri açısından zengin olan Brezilya ise cevher ihracatı ile öne çıkmaktadır. Avusturya, Kanada, Hindistan ihraç miktarlarına bakıldığında; Hindistan, Çelik sektöründe Çin'den sonra Dünya'nın en hızlı büyüyen ülkelerinden biri konumundadır. Hindistan Demir cevheri, Kanada koklaşabilir kömür açısından zengin olup, hammadde ihracatı ile öne çıkmaktadırlar. Amerika, Avusturya ve Hollanda ise katma değeri yüksek çelik ürünleri ihracatını gerçekleştiren ülkelerdir.

Sonuçta bulunduğu küme açısından bakıldığında, göreceli olarak katma değeri yüksek çelik ürünler ihraç eden ülkelerden biri olan Türkiye'nin, üretim ve ihracat noktasında yeni tip mamüllere yapacağı yönelimlerle, bu ihraç seviyesini yükseltebileceği bir potansiyeli vardır. Bulunduğu küme ele alınacak olursa ülkemiz açısından istikrarlı yeni üretim çeşitleriyle yenilikçi üretim anlayışını benimseyen ülkemiz açısından bulunulan küme gelişmeye açık bir seyir göstermektedir.

\section{Kaynaklar}

[1]. T.C. Bilim, Sanayi ve Teknoloji Bakanlığı Demir - Çelik Sektörü Raporu, 2012:4.

[2]. Türkiye Odalar ve Borsalar Birliği, "Türkiye Demir ve Demir D1şı Metaller Meclisi Sektör Raporu", ISBN: 978, Ankara, 2010.

[3]. Atgür, M. 2006. “Avrupa Birliği’ne Uyum Sürecinde Türkiye’de Demir - Çelik Sektörü: Analizi, Sorunlar ve Çözüm Önerileri”, Balıkesir Üniversitesi, Sosyal Bilimler Enstitüsü, İktisat Anabilim Dalı, Yüksek Lisans Tezi, Tez No: 206628.

[4]. T.C. Sanayi ve Ticaret Bakanlığı Demir Çelik Sektörü Raporu, 2011:7.

[5]. T.C. Sanayi ve Ticaret Bakanlığı Demir Çelik Sektörü Raporu, 2011:8. 
[6]. T.C. Bilim, Sanayi Ve Teknoloji Bakanlığı Demir Çelik Sektörü Raporu, 2012.

[7]. T.C. Bilim, Sanayi Ve Teknoloji Bakanlığı Demir Çelik Sektörü Raporu, 2012: 12.

[8]. Çelik Sektörüne İlişkin Ab Müktesebat Rehberi, CPS Corporate\&Public Strategy Advisory Group, Brüksel-İstanbul, 2011.

[9]. Belen, Çakmak ve Yıldırım, 2011: 17.

[10]. DÇÜD, Çelik dergisi, Mayıs 2011: 28.

[11]. Eurofer Ekonomi ve Çelik Piyasalarının Görünümü 2011-2012 Raporu, Demir Çelik Sektörü / Rekabet Gücü Raporu / 2011 Sektörel Rekabet Gücü Raporları Dizisi, Ekim 2011.

[12]. Çelik Dergisi, 2010 yılı Raporu, 2011.

[13]. ERUZ, Burcu; “Türk Demir Çelik Sektörünün Yeniden Yapılandırılması”, Hacettepe Üniversitesi Sosyal Bilimler Enstitüsü, Ankara, 2003.

[14]. Türkiye Odalar ve Borsalar Birliğii, 2011: 27.

[15]. World Steel Assocoiation, "Steel Statistical Yearbook 2010", 2011, 7-9. http://www.worldsteel.org, (03.07.2012).

[16]. Ordu, B., Veri Madenciliğinde Sınıflayıı Teknikler İle Demir Çelik Sektöründe Uzun Ürünlerin Üretimine İlişkin Bir Tahmin Modellemesi, Sosyal Bilimler Enstitüsü, İşletme ABD Yüksek Lisans Tezi, Karabük Üniversitesi, 2013.

[17]. Birleşik Metal İşçileri Sendikası. 2003. “Demir Çelik Sektörü Raporu” Sayı:2 (6).

[18]. Koca M.A. 2008. ” Türk Demir Çelik Sanayi İçin Strateji Önerileri: Bütünleşme Ve Ortak Girdi Temini”, 5-6, İktisadi Sektörler Ve Koordinasyon Genel Müdürlüğü, Aralık.

[19]. Yıldırım, M. Günay ve G. Dönmez, A. 2012. “ Demir Çelik Sektörünün Rekabet Gücü: Karabük İli Örneği” International Iron\& Steel Symposium, 02-04 April, KARABÜK.

[20]. Öztürk, R. ve Fındık, M. 2012. "Türkiye'de Demir-Çelik Sektörünün Yapısal Analizi”, International Iron\& Steel Symposium, 02-04 April, Karabük, 1261.

[21]. Neil, T. H. (2002). Applied Multivariate Analysis, Secaucus, NJ, USA: Springer-Verlag New York.

[22]. Kalaycı, Ş.: SPSS Uygulamalı Çok Değişkenli İstatistik Teknikleri, 4. Baskı, Asil Yayın Dağıtım, 2009.

[23]. Hair, J. F.,Anderson, R.E., Tatham, RL. (1998). Multivariate Data Analysis, New Jersey: Prentice Hall Inc.. 